\title{
HUBUNGAN ANTARA SENSE OF HUMOR DAN BURNOUT PADA GURU SD DI JAKARTA TIMUR
}

\author{
Lupi Yudhaningrum* \\ Aulia Hanifah** \\ *Universitas Negeri Jakarta \\ **Universitas Negeri Jakarta
}

DOI:https://doi.org/10.21009/JPPP.082.02

Alamat Korespondensi:

Auliaahnfh@gmail.com

\begin{abstract}
This study aims to determine the relationship between sense of humor with burnout on elementary school teachers in Jakarta. This research uses quantitative methods. The measuring instrument used to measure burnout is the Maslach Burnout Inventory Educators Survey (MBI-ES). Sense of humor is measured by the Multidimensional Sense of Humor Scale (MSHS) by Thorson and Powell. The statistical method used to analyze the data of this study is the Spearman rank correlation. The results showed a significance value ( $p$ ) of 0.010 ( $p<0.05)$. These results indicate that the hypothesis in this study is accepted that there is a significant relationship between sense of humor with burnout on elementary school teachers in East Jakarta. A negative sign on $r$ count indicates the two variables have a non-directional relationship.
\end{abstract}

Keywords

burnout, sense of humor, elementary school teacher.

\section{Pendahuluan}

Guru memiliki peran yang sangat penting dalam dunia pendidikan. Guru diharapkan dapat menjadi panutan yang baik bagi murid. Selain itu, guru memiliki tuntutan yang mengharuskan mendidik para siswa menjadi generasi penerus bangsa yang pandai. Menurut Undang-Undang Guru dan Dosen nomor 14/2006 (dalam Suprianto, 2013) ditegaskan bahwa guru adalah agen pembelajaran. Konsekuensi dari predikat ini yaitu guru harus merancang pembelajaran yang efektif sehingga proses pembelajaran mampu memberikan jaminan (garansi) setelah pembelajaran selesai siswa mampu menguasai kompetensi yang ditargetkan.

Baru- baru ini, peningkatan kualitas guru digalakkan agar dapat terciptanya pendidikan yang lebih baik. Sebanyak 1.200 guru Pendidikan Anak Usia Dini (PAUD) hingga SMA dikirim oleh Kementerian Pendidikan dan Kebudayaan (Kemendikbud) ke-12 negara. Di antaranya yaitu Finlandia, Australia, India, Korea, Jerman, Jepang, Prancis, Singapura, China, Rumania, dan Hong Kong. Guru-guru tersebut diikutkan pelatihan selama 3 minggu agar para guru mendapatkan pengalaman dalam sistem pembelajaran di era Revolusi Industri 4.0 (sindonews.com). Banyak PR yang harus guru kejar untuk mencapai harapan bagi pendidikan Indonesia tersebut.

Namun, berkebalikan dengan tuntutan dan resiko yang harus para guru hadapi tadi, feed back yang diberikan terhadap perjuangan pahlawan tanpa tanda jasa tersebut tidak sebanding dengan apa yang para guru harus lakukan. Di kutip dari kompas.com, hak guru kerap diberikan tidak sesuai dengan waktu yang ditentukan, tunjangan profesi guru nyaris selalu terlambat disetiap daerah. Padahal dalam UU guru dan dosen Pasal 1

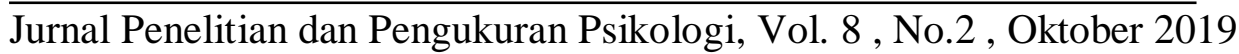


Lupi Yudhaningrum

Aulia Hanifah

ayat (1) huruf a, tertera jelas jika guru berhak mendapat penghasilan di atas kebutuhan hidup minimum dan kesejahteraan sosial.

Peneliti melakukan wawancara terhadap guru SD di Jakarta Timur. Peneliti mengajukan beberapa pertanyaan terbuka terkait burnout. Hasilnya, guru-guru tersebut mengaku burnout pada pekerjaannya. Mereka sempat merasa ingin mengundurkan diri dan malas bekerja dan guru lainnya merasakan kelelahan fisik.

Hasil dari studi pendahuluan dapat dikatakan guru SD memiliki tugas mengajar yang monoton dibandingkan guru Sekolah Menegah Pertama (SMP) atau Sekolah Menengah Atas (SMA). Guru sekolah dasar yang mengajar kelas 1 dan 2 pada umumnya menjadi guru kelas yang setiap hari nya bertemu dengan siswa yang sama dan mengajar dari pagi hingga sore semua mata pelajaran yang di jadwalkan (Ayuningtyas, Akbar \& Pratasiwi, 2017). Selain menjelaskan mata pelajaran dan memberikan tugas kepada siswa, guru juga bertanggung jawab atas perkembangan hasil yang dicapai oleh siswa. Guru SD dapat dikatakan bekerja sehari penuh untuk memberikan pelajaran kepada anak didiknya terlebih ketika menjadi guru kelas, keadaankeadaan tersebut yang menyebabkan terjadinya kecenderungan mengalami stres kerja. Penelitian yang dilakukan Dewi (Akbar \& Pratasiwi, 2017) yang dilakukan di kecamatan Pakis Magelang, menunjukkan bahwa tingkat stres kerja guru SD lebih tinggi dibandingkan dengan guru SMP. Stres kerja yang dialami terus menerus, akan mengakibatkan terjadinya burnout.

Cherniss (dalam Widiastuti \& Astuti, 2008), memberikan gambaran burnout sebagai penarikan diri secara psikologis dari pekerjaan yang dilakukan atas reaksi dari stres dan ketidakpuasan terhadap situasi kerja yang berlebihan atau berkepanjangan. Pines dan Aronson (dalam Widiastuti \& Astuti, 2008) juga berpendapat bahwa burnout adalah bentuk ketegangan atau tekanan psikis yang berhubungan dengan stress yang kronik, dialami seseorang dari hari ke hari, serta ditandai dengan kelelahan fisik, mental, dan emosional.

Definisi burnout oleh Maslach dan Jackson (dalam Maslach dkk, 2017) merupakan sindrom kelelahan emosional, depersonalisasi dan berkurangnya pencapaian pribadi, hal ini dapat terjadi di antara individu yang melakukan pekerjaan yang bertemu dengan orang lain atau
Hubungan antara Sense of Humor dengan Burnout pada Guru SD di Jakarta Timur

pekerjaan jasa. kelelahan dapat menyebabkan penurunan kualitas pelayanan atau layanan yang disediakan (menjadi faktor pergantian pekerjaan, absensi, dan semangat kerja yang rendah), hal tersebut memiliki kemungkinan berkorelasi dengan berbagai indeks disfungsi pribadi, termasuk kelelahan fisik, insomnia, peningkatan penggunaan alkohol dan obat-obatan, dan masalah perkawinan dan keluarga (dalam Maslach dkk, 2017).

Menurut Freudenberger (dalam Tumkaya, 2006) burnout merupakan kegagalan pribadi, kelelahan, dan tuntutan berlebihan pada energi, daya, dan sumber daya. Demikian pula, Maslach dan Jackson (dalam Tumkaya, 2006) mengartikan burnout sebagai kelelahan fisik, emosional, dan intelektual, kelelahan kronis, ketidakberdayaan, keputusasaan, perkembangan ego negatif, dan sikap negatif terhadap pekerjaan, kehidupan dan orang lain. Subdimensi burnout termasuk depersonalisasi orang terhadap kolega mereka, perasaan kelelahan emosional, dan penurunan tingkat pencapaian pribadi dan suffciency emosional. Sesuai dengan yang diungkapkan oleh Sihotang (dalam Ekawanti \& Mulyana, 2016) jika burnout adalah keadaan dimana individu merasakan stres dalam jangka waktu yang lama dan dengan intensitas yang cukup tinggi, ditandai dengan kelelahan fisik, mental, dan emosional, kurangnya perhatian kepada orang lain maupun pekerjaan akibat dari tekanan berkepanjangan yang dialami dalam situasi kerja, terutama pada pekerjaan pelayanan sosial, serta rendahnya penghargaan terhadap diri sendiri yang mengakibatkan individu merasa terpisah dari lingkungannya.

Dari pengertian para ahli tentang burnout di atas, dapat disimpulkan bahwa burnout adalah dampak dari stres yang berkepanjangan, yang menyebabkan hilangnya emosi terhadap pekerjaan, tidak terdapat gairah akan mengerjakan pekerjaan, apatis, dan dapat berujung kepada depresi. Burnout disebabkan karena melakukan pekerjaan yang terlalu intens.

Risiko burnout dapat muncul ketika tuntutan pekerjaan lebih besar dari kondisi dan sumber daya yang ada. Namun, turunnya kinerja dan antusiasme oleh pekerja juga terjadi ketika sumber daya pekerjaan terbatas dan kondisinya buruk (Demerouti dkk, dalam Tumkaya, 2006). Sejumlah besar peneliti yang berurusan dengan efek burnout telah menekankan bahwa burnout fisik, emosional, 
Lupi Yudhaningrum

Aulia Hanifah

dan intelektual saling terkait (Pines dkk, dalam Tumkaya, 2006).

Aspek penentu dari sindrom burnout yaitu meningkatnya perasaan kelelahan emosional. Ketika sumber daya emosional mereka menipis, pekerja merasa tidak lagi dapat memberikan diri mereka sendiri pada tingkat psikologis. Aspek lain yaitu pengembangan sikap dan perasaan negatif dan sinis kepada klien. Reaksi negatif kepada klien tersebut dapat dikaitkan dengan pengalaman kelelahan emosional, yaitu dua aspek kelelahan ini tampaknya agak terkait. Persepsi tidak berperasaan atau bahkan tidak manusiawi dari orang lain ini dapat membuat staf memandang klien mereka pantas mendapatkan masalah mereka (Ryan, dalam Maslach \& Jackson, 1981), dan prevalensi di antara para profesional layanan manusia dari sikap negatif terhadap klien ini telah didokumentasikan dengan baik (Wills, dalam Maslach \& Jackson, 1981). Aspek ketiga dari sindrom burnout yaitu kecenderungan untuk mengevaluasi diri sendiri secara negatif, khususnya yang berkaitan dengan pekerjaan seseorang dengan klien. Pekerja merasa tidak bahagia tentang diri mereka sendiri dan tidak puas dengan prestasi mereka di pekerjaan.

Proses burnout dipengaruhi tidak hanya oleh variabel eksternal, seperti beban kerja (Sarros dan Sarros 1987, dalam Tumkaya, 2007), kurangnya dukungan sosial (Cheuk dan Wong 1995, dalam Tumkaya, 2007), kurangnya dukungan manajerial (Brissie et al. 1988, dalam Tumkaya, 2007), dan usia dan pengalaman mengajar bertahun-tahun (Tumkaya, 1996, dalam Tumkaya, 2007), tetapi juga oleh atribut pribadi, seperti cara mengatasi stres (Chan dan Hui 1995, dalam Tumkaya, 2007), dan locus of control (Lunenburg dan Cadavid 1992; Tumkaya 2001, dalam Tumkaya, 2007).

Burnout dapat mengakibatkan penurunan prestasi kerja yang menyebabkan kurangnya minat dalam pekerjaan, gangguan kehidupan keluarga dan hubungan pribadi, ketidakhadiran, dan keinginan untuk mengubah pekerjaan (Cherniss 1980; Gaines dan Jermier 1983; Maslach dan Jackson 1985; Perlman dan Hartman 1982; Pines dkk, 198; dalam Tumkaya, 2007).

Dengan intensi mengalami burnout yang mengancam guru SD tersebut, dapat diatasi dengan salah satu mekanisme penghilang stres
Hubungan antara Sense of Humor dengan Burnout pada Guru SD di Jakarta Timur

yang dapat digunakan para guru yaitu humor yang dibagikan kepada rekan kerjanya. Berkman (dalam Miller, 2008) dan Cohen dan Wills (dalam Miller, 2008) mengemukakan bahwa jejaring sosial seseorang dapat memediasi dampak tuntutan kehidupan pada kesehatan dan kesejahteraan. Singkatnya, stresor baik di dalam maupun di luar kelas berkontribusi terhadap tempat kerja yang kompleks dan sering tidak menguntungkan bagi para guru. Oleh karena itu, humor dapat membantu mengurangi tekanan ini dan juga berfungsi untuk meningkatkan persepsi dan sikap individu sehubungan dengan pekerjaan mereka. Humor yang digunakan oleh orang dewasa yang bekerja bersama di lingkungan sekolah dapat menciptakan dan mempertahankan lingkungan kerja dan belajar yang positif.

Studi yang melibatkan hubungan antara humor dan burnout yang dilakukan pada dosen universitas (Tumkaya 2007) telah menunjukkan hasil yang berhubungan secara signifikan. Satu studi yang dilakukan oleh Kelly (2002) menunjukkan bahwa individu yang memiliki sense of humor cenderung tidak khawatir. Demikian pula, Cann dkk. (dalam Malinowski, 2013) menemukan bahwa sense of humor tidak hanya dapat mengurangi jumlah kekhawatiran dan kecemasan yang dialami seseorang, namun juga dapat menghasilkan emosi positif. Yang paling menonjol adalah penelitian yang dilakukan oleh Szabo (dalam Malinowski, 2013), yang menunjukkan bahwa penggunaan humor dapat menghasilkan perubahan psikologis positif yang lebih besar dibandingkan dengan olahraga. Selain itu, Szabo dkk. (dalam Malinowski, 2013) melaporkan bahwa humor memiliki dampak yang lebih besar pada kesejahteraan psikologis individu dibandingkan dengan latihan aerobik dan musik.

Individu dengan sense of humor yang lebih besar dianggap lebih mampu mengatasi stres, bergaul dengan orang lain, dan menikmati kesehatan mental dan bahkan fisik yang lebih baik (Lefcourt, 2001, dalam Tumkaya, 2007). Salah satu cara untuk mengatasi tekanan dan stres yaitu dengan humor. Menurut Hodgkinson (dalam Sukoco, 2014) humor dapat menimbulkan refleks tertawa, dan tertawa merupakan obat terbaik untuk melawan stres. Untuk dapat mengamati, merasakan atau mengungkapkan humor, individu memerlukan kepekaan terhadap humor (sense of humor). Menurut Irwin dkk (dalam Sukoco, 2014), sense of humor adalah sebuah kemampuan 
Lupi Yudhaningrum

Aulia Hanifah

seseorang atau individu untuk melihat suatu sisi yang lebih ringan dan lebih lucu dalam kehidupannya.

Martin (dalam Kelly, 2002) mendefinisikan sense of humor sebagai pemburu, memahami, menghargai, dan menciptakan humor. Konsisten dengan definisi umum ini, Thorson dan Powell (dalam Kelly, 2002) mengemukakan bahwa rasa humor terdiri dari beberapa elemen, termasuk pengakuan diri sendiri sebagai humor, pengakuan humor orang lain, penghargaan humor, kecenderungan untuk tertawa, sebuah perspektif yang memungkinkan suatu penghargaan atas absurditas hidup, dan penggunaan humor untuk menghadapi masalah. Menurut McGhee (dalam Kelly, 2002) humor adalah gabungan dari sikap main-main dan kemampuan untuk bermain pada ide-ide. Kemampuan kognitif untuk memanipulasi dan membingkai ulang ide-ide yang memungkinkan orang-orang dengan selera humor yang baik untuk melihat peristiwaperistiwa yang tidak menyenangkan sebagai hal yang lucu dan bukannya menakutkan ataupun menyebalkan. Oleh karena itu, tidak mengherankan, jika individu dengan selera humor yang lebih besar tidak mendukung depresi, kesepian, suasana hati yang negatif, dan ketidakmampuan sosial (Kelly, 2002) dan mendukung motivasi tugas, keceriaan, harga diri, kepercayaan, dan dominasi sosial (Kelly, 2002).

Eysenck (dalam Martin \& Lefcourt, 1984) menunjukkan bahwa istilah sense of humor dapat digunakan setidaknya dalam tiga cara: (a) rasa konformis, menekankan tingkat kesamaan antara apresiasi orang terhadap materi lucu; (b) arti kuantitatif, mengacu pada seberapa sering seseorang tertawa dan tersenyum dan betapa mudahnya dia geli; dan (c) pengertian produktif, dengan fokus pada sejauh mana orang tersebut menceritakan kisah lucu dan menghibur orang lain.

Dimensi sense of humor menurut Thorson dan Powell (1993) yaitu humor production, humor appreciation, coping humor, dan attitudes toward humor and humorous people.

Dari pengertian sense of humor oleh para ahli tadi, dapat disimpulkan bahwa sense of humor adalah sifat yang dimiliki oleh individu yang dapat merasakan, menciptakan, menghargai sesuatu yang lucu. Orang yang memiki sense of humor yang baik ini dapat mereduksi situasi penuh stres, karena mereka dapat merubah
Hubungan antara Sense of Humor dengan Burnout pada Guru SD di Jakarta Timur

kognitif mereka dari situasi penuh tekanan menjadi situasi yang dapat ditertawakan secara cepat. Mereka pun dapat lebih mudah bergaul di lingkungan sosial karena dianggap menyenangkan, juga dapat membantu orang lain dalam mereduksi masalahnya.

Dari penelitian- penelitian sebelumnya, tidak ada yang mengangkat sense of humor dan burnout, penelitian sebelumnya banyak membahas sense of humor dengan stres salah satunya yaitu penelitian hubungan sense of humor dengan stres pada mahasiswa baru fakultas psikologi yang dilakukan oleh Sukoco (2014) dengan hasil yang di dapat berupa terdapat hubungan negatif antara sense of humor dengan stres pada mahasiswa baru Fakultas Psikologi Universitas Surabaya angkatan 2013, burnout sendiri memiliki keterkaitan dengan stres, yaitu burnout merupakan tahap selanjutnya dari stres yang terus menerus. Stres kronis dapat melemahkan secara emosional terutama ketika individu mengalami ketidakmampuan untuk mengendalikan atau mengurangi stres ke tingkat yang dapat dikelola (Talbot \& Lumden,2000).

Di Indonesia, istilah burnout tidak sepopuler stres terutama di kalangan para guru yang masih menganggap asing istilah burnout (Firdaus, 2006, dalam Widiastuti \& Astuti, 2008). Dengan adanya alasan tersebut, peneliti ingin mengenalkan istilah burnout kepada para pekerja terutama guru. Oleh karena masih sangat jarang penelitian yang mengangkat tema sense of humor dengan burnout, peneliti tertarik untuk meneliti hubungan sense of humor dengan burnout pada guru SD di Jakarta Timur.

Tujuan dari penelitian ini yaitu untuk mengetahui hubungan sense of humor dengan burnout pada guru SD di Jakarta Timur.

\section{Metode Penelitian}

Dalam penelitian ini menggunakan pendekatan kuantitatif. Penelitian ini termasuk ke dalam penelitian korelasional, korelasional adalah metode yang menggambarkan secara kuantitatif asosiasi ataupun relasi satu variable interval dengan interval lainnya.

Populasi yang akan digunakan dalam penelitian ini adalah guru SD di Jakarta Timur. Teknik pengambilan sampel pada penelitian ini dengan cara Simple random sampling merupakan teknik penentuan sampel dari populasi secara acak tanpa memperhatikan strata yang ada dalam populasi itu. Cara demikian dilakukan bila anggota 
Lupi Yudhaningrum

Aulia Hanifah

populasi dianggap homogen (Sudaryono, 2018) Dengan cara mengacak sekolah SD yang berada di Jakarta Timur.

Teknik pengumpulan data yang digunakan dalam penelitian ini adalah teknik angket atau kuisioner. Terdapat dua buah instrumen penelitian yang digunakan dalam penelitian ini, diantaranya Educators Survey-Maslach Burnout Inventory (MBI-ES) untuk mengukur burnout pada guru.

Instrumen MBI ES ini terdiri dari 22 item, dengan 14 item favorable dan 8 item unfavorable, instrumen MBI ES ini memiliki 7 pilihan jawaban yaitu mulai dari tidak pernah $(0$ poin) hingga setiap hari (6 poin). Multidimensional Sense of Humor Scale (MSHS) untuk mengukur sense of humor. MHSH terdiri dari 29 item, dengan 7 item unfavorable dan 22 item favorable, MHSH memiliki empat pilihan jawaban yang menunjukkan frekuensi sense of humor individu, diantaranya Sangat Setuju (SS), Setuju (S), Tidak Setuju (TS), dan Sangat Tidak Setuju (STS).

Tabel 1. Kategorisasi Skor Burnout
Hubungan antara Sense of Humor dengan Burnout pada Guru SD di Jakarta Timur
Sedangkan reliabilitas per aspek yaitu; aspek kelelahan emosi 0,706; depersonalisasi 0,678, dan untuk aspek penurunan pencapaian pribadi yaitu 0,657; setiap aspek dalam burnout ini dikategorikan reliabel. Kemudian, nilai reliabilitas instrumen sense of humor setelah dilakukan uji coba sebesar 0,826 yang dikategorikan reliabel.

Setelah melakukan uji coba validitas dan reliabilitas, peneliti kemudian melakukan penelitian dengan mendatangi 15 SD yang berada di Jakarta Timur pada tanggal 22 Juli 2019 sampai dengan 1 Agustus 2019. Total subjek penelitian yang diperoleh sebanyak 136 orang.

Berdasarkan pengujian dengan menggunakan uji korelasi product moment oleh rank Spearman, diketahui jika $r$ hitung sebesar -0,221 dan $r$ tabel $0,168, \mathrm{r}$ hitung $>\mathrm{r}$ tabel. Sedangkan pada nilai $\mathrm{p}=$ 0,010. Dengan demikian nilai $p$ lebih kecil daripada nilai $\alpha=0,05$. Jadi, dapat disimpulkan bahwa Ho ditolak dan Ha diterima. Kesimpulan dari uji analisis korelasi product moment oleh rank Spearman ini adalah terdapat hubungan yang signifikan antara sense of humor dengan burnout pada guru SD di Jakarta Timur. Hubungan negatif tersebut memiliki arti jika sense of humor memiliki hubungan yang terbalik dengan burnout.

\begin{tabular}{llll}
\hline Kategorisasi & Skor & Frekuensi & Presentase \\
\hline Tinggi & $\mathrm{X}>48,00$ & 5 & $3,7 \%$ \\
Rendah & $\mathrm{X} \leq 48,00$ & 131 & $96,3 \%$ \\
\hline Total & & $\mathbf{1 3 6}$ & $\mathbf{1 0 0 \%}$
\end{tabular}

Uji coba instrumen diberikan kepada individu yang bekerja sebagai guru SMP dan SMA di sekolah yang berada di Jakarta Timur yaitu sebanyak 51 orang guru. Perhitungan uji reliabilitas dan validitas dalam penelitian ini dilakukan dengan menggunakan SPSS 25.
Berdasarkan tabel 1. diketahui bahwa subjek yang memiliki tingkat burnout tinggi sebanyak 3 orang $(2,2 \%)$ dan yang memiliki tingkat burnout rendah sebanyak 133 orang $(97,8 \%)$. Dapat disimpulkan bahwa hampir keseluruhan responden memiliki tingkat burnout rendah.

Tabel 2. Kategorisasi Skor Sense of Humor

\begin{tabular}{cccc}
\hline Kategorisasi & Skor & Frekuensi & Presentase \\
\hline Tinggi & $X>50,00$ & 125 & $91,9 \%$ \\
Rendah & $X \leq 50,00$ & 11 & $8,1 \%$ \\
\hline Total & & $\mathbf{1 3 6}$ & $\mathbf{1 0 0 \%}$ \\
\hline
\end{tabular}

\section{Hasil Penelitian dan Diskusi}

Sebelum penelitian ini dilakukan, peneliti melakukan uji coba instrumen terlebih dahulu. Diketahui nilai reliabilitas keseluruhan untuk instrumen burnout setelah dilakukan uji coba sebesar 0,811 yang dikategorikan reliabel.
Berdasarkan tabel 2. diketahui bahwa subjek yang memiliki tingkat sense of humor tinggi sebanyak 129 orang $(94,9 \%)$ dan yang memiliki tingkat sense of humor rendah sebanyak 7 orang $(5,1 \%)$. Dapat disimpulkan bahwa hampir keseluruhan responden memiliki tingkat sense of 
Lupi Yudhaningrum

Aulia Hanifah

\section{humor tinggi.}

Seperti halnya yang dikatakan oleh Wooten jika humor menyediakan cara untuk berbagi frustrasi umum yang pada gilirannya dapat meningkatkan kekompakan di antara rekan kerja. Humor juga telah diidentifikasi sebagai alat komunikasi yang, jika digunakan secara efektif, dapat mencegah kelelahan dan menciptakan ketahanan terhadap stres (Talbot \& Lumden, 2000) sehingga mengurangi dampaknya (Talbot \& Lumden, 2000). Humor dapat bertindak secara langsung pada depresi atau dapat bertindak sebagai penyangga terhadap efek negatif dari tekanan psikologis (Overholser, 1992).

Humor terbukti dapat menjadi salah satu mekanisme koping untuk mencegah terjadinya burnout di kalangan guru. Humor, menurut McGhee (dalam Kelly, 2002) menggabungkan sikap main-main dan kemampuan bertepatan untuk bermain pada ide-ide. Suatu kemampuan kognitif untuk memanipulasi dan membingkai kembali ide-ide yang memungkinkan orangorang dengan selera humor untuk melihat peristiwa-peristiwa yang tidak menyenangkan menjadi hal yang lucu dan bukannya menakutkan ataupun menyebalkan.

Oleh karena itu, tidak mengherankan, jika individu dengan selera humor yang lebih besar tidak mengalami depresi, kesepian, suasana hati yang negatif, dan ketidakmampuan sosial (Kelly, 2002) dan baik dalam motivasi tugas, keceriaan, harga diri, kepercayaan, dan dominasi sosial (Kelly, 2002). Juga humor telah diidentifikasi sebagai manajer stres di tempat kerja (Morreall 1991, dalam Talbot \& Lumden, 2000).

Humor menyediakan cara untuk berbagi frustrasi umum yang pada gilirannya dapat meningkatkan kekompakan di antara rekan kerja. Humor juga telah diidentifikasi sebagai alat komunikasi yang jika digunakan secara efektif, dapat mencegah kelelahan dan menciptakan ketahanan terhadap stres (Wooten 1996, dalam Talbot \& Lumden, 2000) sehingga mengurangi dampaknya (Nezu dkk, 1988, dalam Talbot \& Lumden, 2000).

\section{Kesimpulan}

Berdasarkan hasil pengujian hipotesis secara statistik dapat disimpulkan bahwa terdapat hubungan yang signifikan antara sense of humor dengan burnout pada Guru SD di Jakarta Timur.
Hubungan antara Sense of Humor dengan Burnout pada Guru SD di Jakarta Timur

Hampir seluruh subjek penelitian memiliki sense of humor yang tinggi, dan sebaliknya. Hampir seluruh subjek penelitian memiliki tingkat burnout yang rendah dan sense of humor yang tinggi. Hal itu memburktikan bahwa humor terbukti dapat menjadi salah satu mekanisme koping untuk mencegah terjadinya burnout di kalangan guru.

\section{Daftar Pustaka}

Akbar, Z., Pratasiwi, R. (2017). Resiliensi Diri dan Stres Kerja pada Guru Sekolah Dasar. Jurnal Penelitian dan Pengukuran Psikologi, 6(2). http://doi.org/10. 21009/jppp.

Kelly, W. E.(2002). An Investigation of Worry and Sense of Humor. The Journal uf Psychology,136(6), 657-666.

Malinowski, A. J. (2013). Characteristics of Job Burnout and Humor among Psychotherapists. Humor, 26(1), 117 - 133. DOI 10.1515/humor2013-0007.

Martin, R. A., Lefcourt, H. M. (1984). Situational Humor Response Questionnaire: Quantitative Measure of Sense of Humor. Journal of Personality and Social Psychology, 47(I), 145155.

Maslach, C., Jackson, S. E. (1981). The measurement of experienced burnout. Journal Of Occupational Behaviour, 2, 99-113.

Maslach, C., Schaufeli, W. B. (2017). Historical and Conceptual Developmet of Burnout, In C. Maslach, W. B. Schaufeli, \& T. Marek (Eds), Professional Burnout: Recent Developments in Theory and Research (pp, 1-16). New York.

Miller, B. (2008). The Use and Effect of Humor in the School Work Place. Dissertation. University of Oregon.

Overholser, J.C. (1992). Sense of Humor When Coping with Life Stress. Person Indiuidu, 13(7), 799-804.

Riana, A. (2012). 4 Masalah Guru yang Tak Pernah Selesai. Retrieve from https://edukasi.kompas.com/read/2012/11/26/1 337430/4. Di akses pada tanggal 11 April 
Lupi Yudhaningrum

Aulia Hanifah

2019.

Sudaryono. (2018). Metodologi Penelitian. Depok: Rajawali Pers.

Suprianto, E. (2013). Tuntutan Kompetensi Baru Bagi Guru Dalam Mewujudkan Pembelajaran Yang Efektif. Retrieve from https://publikasiilmiah.ums.ac.id/ bitstream/handle/11617/3516/2_Tuntutan_Ko mpetensi_Baru_Bagi_Guru_Dalam_Mewujud kan.pdf?sequence $=1 \&$ isAllowed $=\mathrm{y}$.

Talbot, L. A., Lumden, D. B. (2000). On The Association Between Humor and Burnout. Humor, 13(4), pp. 419-428.

Thorson, J. A., Powell, F. C.(1993). Development and Validation of a Multidimensional Sense of Humor Scale. Journal of Clinical Psychology, 49(I).

Tumkaya, S. (2006). Faculty Burnout in Relation to Work Environment and Humor as a Coping
Hubungan antara Sense of Humor dengan Burnout pada Guru SD di Jakarta Timur

Sukoco, A.S.P. (2014). Jurnal Tugas Akhir Hubungan Sense of Humor Dengan Stres Pada Mahasiswa Baru Fakultas Psikologi. Jurnal Ilmiah Mahasiswa Universitas Surabaya, 3(1).

Strategy. Educational Sciences: Theory \& Practice. 6(3). 911-921.

Tumkaya, S. (2007). Burnout And Humor Relationship Among University Lecturers. Humor, 20(1), 73-92. DOI 10.1515.

Wahab Firmansyah (2019). Ikut Pelatihan di Luar Negeri, Kompetensi 1.200 Guru Digembleng. Retrieve from https://nasional.sindonews.com/read/1382785/ 144/ ikut-pelatihan-di-luar-negeri-kompetensi1200-guru-digembleng 1551338250. Di akses pada tanggal 12 April 2019.

Widiastuti, D.Z., Astuti, K. (2008). Hubungan Antara Kepribadian Hardiness dengan Burnout pada Guru Sekolah Dasar. Jurnal Insight, 6(2). 